
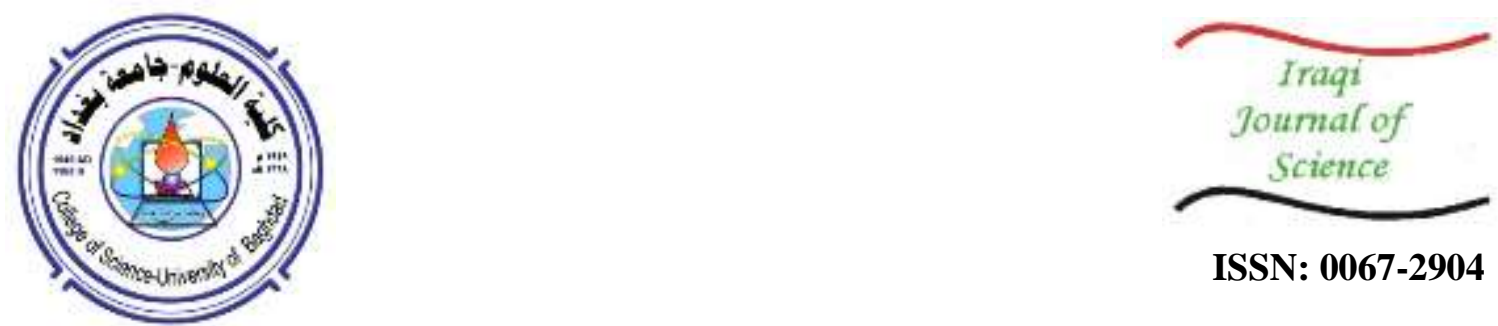

ISSN: 0067-2904

\title{
Assessment of Inflammation, Comorbidity and Demographic Factors in Patients with Kidney Disease in Baghdad
}

\author{
Yasamen R. Humudat* ${ }^{1}$, Saadi K. Al-Naseri ${ }^{1}$, Yaaroub F. Al-Fatlawy ${ }^{2}$ \\ ${ }^{1}$ Environment and Water Directorate, Ministry of Science and Technology, Baghdad, Iraq \\ ${ }^{2}$ University of Baghdad, College of Science, Dept. of Biology Ministry of Higher Education and Scientific \\ Research, Baghdad, Iraq
}

\begin{abstract}
Inflammation markers are significantly higher among hemodialysis (HD) patients, which have been associated with chronic activation of the immune system. Hemodialysis centers in Baghdad appear to be taking measures with low adequacy and frequency of dialysis sessions, which can be a reason for decreased kidney functions. Therefore, the objective of this study focuses on the assessment of different aspects of hemodialysis for regular HD patients in Baghdad, including inflammatory markers (serum C-reactive protein, CRP, and erythrocyte sedimentation rate, ESR), dialysis dose, comorbidities, and demographic factors for a period of one year (2018), the assessment covered four major hospitals in Baghdad namely (Al-Kindi, Baghdad Educational, Al-Imamain Al-Jwadian, and AlYarmouk). The study involved 320 adult (chronic kidney disease; non hepatitis virus) patients (55\% male and $45 \%$ female) treated with regular hemodialysis. When compared with the normal values specified by manufacturers for the number of measurement of these indicators. Inflammation markers were high in HD patients were $66.2 \%$ of patients recorded elevated of CRP and $87.7 \%$ for ESR with no significant difference between males and females, but the origin of chronic inflammation in the patient's remains unclear. Moreover, the majority of HD patients were non-educated; illustring that higher education is possibly associated with lower disease incidence as compared to those who never finished high school. Finally, most of these hospitals, average hemodialysis treatment lasts about three hours and is done two times per week.
\end{abstract}

Keywords: Dialysis, hemodialysis patients, inflammation marker, C-reactive protein, Erythrocyte sedimentation rate.

$$
\begin{aligned}
& \text { تقييم علامات الالتهابات والأمراض المصاحبة والعوامل الليموغرفية لمرضى الفشل الكلوي في بغاد } \\
& \text { ياسمين رعد حمودات1"، سعدي كاظم الناصري 1، يعرب فالح الفتلاوي2 }
\end{aligned}
$$

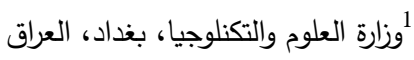

$$
\begin{aligned}
& \text { 2وزارة التعليم العالي والبحث العلمي، بغداد، العراق بلغاد، العرات }
\end{aligned}
$$

علامات الالتهاب تكون أعلى بكثير بين مرضى غسيل الكلى (HD)، والتي ترتبط مع التشيط المزمن

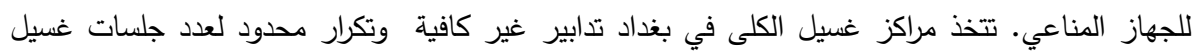

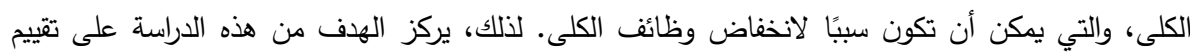




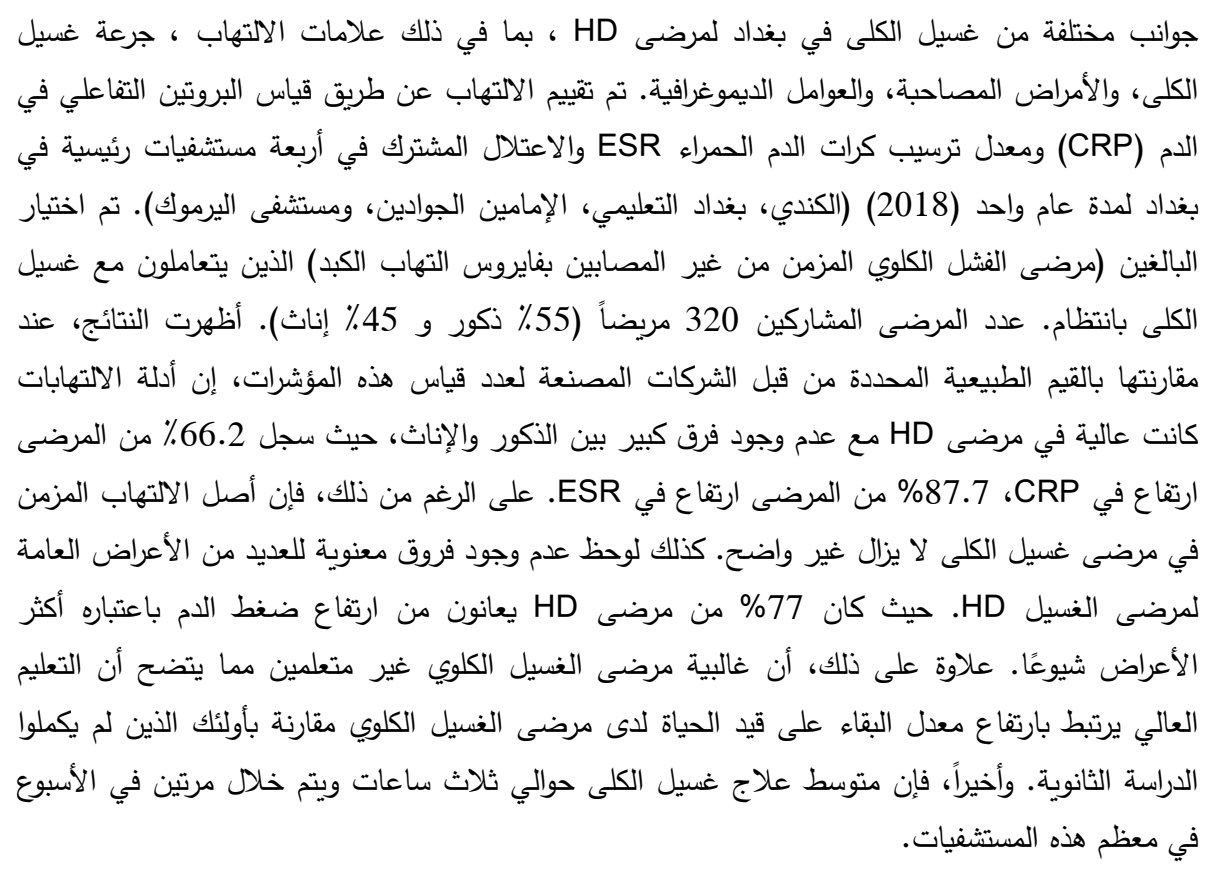

\section{Introduction}

Hemodialysis (HD) is a method of removing accumulated solute from a patient who has a loss of kidney function, the general principle of dialysis is an exchange between the blood and a dialysis fluid via a thin semipermeable membrane as the primary component of the dialyzer [1]. Kidney disease is a major health problem all over the world were considered 12th most prevalent cause of death with representing 1.1 million deaths worldwide in one year [2].

Inflammation markers consider biological indicator in HD patients where most dialysis research noticed elevated of C-reactive protein CRP and erythrocyte sedimentation rate ESR level in patient before dialysis sessions [3]. The traditional dialysis regimen consists of 3 to 4 hours of treatment session for three times a week, which was reported to be associated with decreased levels of inflammation markers [4].

The nature of the association between inflammation and HD can be bidirectional; the inflammation can be both a cause and a consequence in HD patients [5].

Inflammation markers are a reliable, early indicator of active systemic inflammation, as they can help differentiate inflammatory from noninflammatory conditions and also reflect the severity of the inflammatory insult [6]. Starting with the assumption that kidney disease in these patients is characterized by increased procoagulant, an inflammatory marker, coagulation hormone, cardiovascular morbidity and mortality [7].

In Iraq, there are 36 dialysis centers distributed in all the 18 provinces [8]. In Baghdad alone, there are approximately $320 \pm 61$ patients who are regularly registered in those dialysis centers. Each center includes an average of $37 \pm 8$ hemodialysis machines, and the total production capacity for each center varies between $1.5-4.5 \mathrm{~m}^{3} / \mathrm{d}$ depending on their daily operating hours, which ranges from 18 to 24 hours. Water treatment units in those centers work in a uniform manner; i.e. using Reverse Osmosis (RO) units that are usually used for municipal water desalination [9]. These units have the same basic components, but the key differences are the quality of the filters and the number of membranes inside each unit.

The purpose of this study was to assess inflammation, comorbidity and demographic variables in Baghdad patients with kidney disease on regular hemodialysis.

\section{Materials and Methods}

\section{Work Strategy}

This study was carried out from January 2018 to December 2018 with voluntary participation of 320 HD patients' (with no hepatitis virus infection) on regular hemodialysis in four hemodialysis centers in Baghdad-Iraq, namely; Al-Kindi, Baghdad Educational, Al-Imamain Al-Jwadian, and AlYarmouk hospitals. 


\section{Ethical Considerations}

This research was approved by the local ethics committee of the Ministry of Health and Environment. Written permissions were taken from relevant authorities based on a description of the study and its aims, and a signed agreement was made to treat all the individual clinical information as confidential.

\section{Clinical Information}

Clinical information was surveyed for each patient, including age, gender, weight, blood pressure (BP) (it was measured with the help of a sphygmomanometer), fever, frequency and duration of HD sessions per week, medical history, smoking habit, and patients' educational level. In addition, comorbidity symptoms such as abdominal pain, bleeding, diabetes, diarrhea, hypertension, nausea, rash, and vomiting were monitored and recorded during the dialysis sessions of the patients. These data were collected using a questionnaire and were verified with the information of the patients' medical records.

\section{Blood tests}

Blood samples were collected from the venous port of the hemodialysis catheter before adding heparin to the entire blood of regular HD patients. The first $5 \mathrm{IU} / \mathrm{ml}$ of blood were discarded to avoid activation of coagulation due to the puncture trauma [10] while the second $5 \mathrm{IU} / \mathrm{ml}$ were collected and divided into two parts for the following tests:

1. C-reactive protein (CRP): measured by (CRP kit, Humen/ Germany) after separation of serum from blood samples.

2. Erythrocyte sedimentation rate (ESR): blood samples were transferred into tubes with EDTA and used for ESR test according to Biosigma, Italy.

\section{Statistical Analysis}

Statistical analysis was performed using analysis of variance (ANOVA) test to compare different factors of the studied parameters. Independent sample t-test was utilized to evaluate the significant difference between any two independent groups. P-value level of 0.05 was considered for the significant differences between the compared groups. All the statistical analyses were implemented using Excel application 2010 and the evaluated data were expressed as Mean \pm SD and percentage (\%) [11].

\section{Results and Discussion \\ Patient's Characteristics}

As indicated in Table-1 for patient's characteristics, there was in general no significant difference between males and females in the obtained basic health information, except for the age and weight $(\mathrm{P}<0.05)$. The results show that HD patients comprise $178 \pm 5.8$ males and $152 \pm 5.8$ females, with an age of $53 \pm 13$ for males and $49 \pm 16$ ) for females. Similar results, i.e. higher number of males with higher age values, were reported in HD patients from several studies in other parts in the world, such as USA [10] and Greece [12].

Furthermore, the results of HD patients' weight showed that the weight ranges from 37 to $135 \mathrm{~kg}$ $(76 \pm 16.9)$ for males, and from 35 to $120 \mathrm{~kg}(66 \pm 16.6)$ for females. Most of the patients showed normal or even lower weight, which might be due to the hospitalization of HD patients which was reported to have a negative nutritional impact [13].

In respect to the HD patients' body temperature, there was a slight difference as compared to normal body temperature, however, the differences were not significant. Patients' body temperature showed similar characteristics for both genders and ranged from $36-38{ }^{\circ} \mathrm{C}(37 \pm 0.6)$. Nevertheless, low body temperatures for patients with hemodialysis are not uncommon [14].

In addition, the high blood pressure level during the tradialytic period in the patients was found to range from $90-198 \mathrm{~mm} \mathrm{Hg}(150 \pm 20)$ for males and 90-195 mm Hg $(145 \pm 21)$ for females. The low blood pressure level in tradialytic period ranged from $54-130 \mathrm{~mm} \mathrm{Hg}(85 \pm 13)$ for males and 54-119 $\mathrm{mm} \mathrm{Hg}(84 \pm 12)$ for females. The results came in agreement with those reported for a patient's population in the United States [12].

Moreover, the present study showed a small percentage of cigarette smoking HD patients (only $4 \%$ of the male and no smoking females). This is a small percentage when compared to another study conducted in USA where the percentage of cigarette smoking was estimated between 14 and $15 \%$ in HD patients [15]. 
Finally, as related to the level of education, the results showed that only $18 \%(58 \pm 2)$ of the HD patients, mostly males, had an education level of high school or higher, while the majority of the patients were non-educated. The study of Khattak et. al [10] showed that college education is associated with higher survival rate in dialysis patients compared to those who never finished high school. They founded that the $33.5 \%$ of the patients with less than 12 years of education, $34.9 \%$ high school graduates, $16.7 \%$ with some college education, and $14.9 \%$ with a college education and higher education levels.

Table 1-General patients' characteristics and their comparison according to gender.

\begin{tabular}{|c|c|c|c|}
\hline Variables and categories & Value of males & $\begin{array}{l}\text { Value for } \\
\text { females }\end{array}$ & $\begin{array}{c}\text { Significant difference } \\
\text { at } 0.05\end{array}$ \\
\hline $\begin{array}{l}\text { Gender No. of Patients } \pm \text { SD } \\
\text { (Percentage) }\end{array}$ & $\begin{array}{l}178 \pm 5.8 \\
(55.62 \%)\end{array}$ & $\begin{array}{l}142 \pm 5.8 \\
(44.37 \%)\end{array}$ & - \\
\hline Age $($ mean $\pm \mathrm{SD})$ & $(53 \pm 13)$ & $(49 \pm 16)$ & $*$ \\
\hline $\begin{array}{l}\text { Weight range in kg } \\
\quad(\text { mean } \pm \mathrm{SD})\end{array}$ & $\begin{array}{c}37-135 \\
(76 \pm 16.9)\end{array}$ & $\begin{array}{c}35-120 \\
(66 \pm 16.6)\end{array}$ & $*$ \\
\hline $\begin{array}{l}\text { Temperature }{ }^{\circ} \mathrm{C} \text { range } \\
\quad(\text { mean } \pm \mathrm{SD})\end{array}$ & $\begin{array}{c}36-38 \\
(37 \pm 0.6)\end{array}$ & $\begin{array}{c}36-38 \\
(37 \pm 0.6)\end{array}$ & (NS) \\
\hline $\begin{array}{l}\text { High blood pressure mm Hg range } \\
\qquad(\text { mean } \pm \text { SD) }\end{array}$ & $\begin{array}{c}90-198 \\
(150 \pm 20)\end{array}$ & $\begin{array}{l}90-195 \\
(145 \pm 21)\end{array}$ & (NS) \\
\hline $\begin{array}{l}\text { Low blood pressure } \mathrm{mm} \mathrm{Hg} \text { range } \\
\qquad(\text { mean } \pm \mathrm{SD})\end{array}$ & $\begin{array}{c}54-130 \\
(85 \pm 13)\end{array}$ & $\begin{array}{c}54-112 \\
(84 \pm 12)\end{array}$ & (NS) \\
\hline $\begin{array}{l}\text { Current smoking } \% \\
\quad(\text { number } \pm \mathrm{SD})\end{array}$ & $\begin{array}{c}4 \% \\
(12 \pm 0.9)\end{array}$ & $\begin{array}{c}0 \% \\
(0 \pm 0)\end{array}$ & - \\
\hline Education level (High school+) & $\begin{array}{c}10 \% \\
32\end{array}$ & $\begin{array}{l}8 \% \\
26\end{array}$ & (NS) \\
\hline
\end{tabular}

* (P<5\%), NS: Non-Significant.

\section{Patients Symptoms}

Table- 2 summarizes the symptoms of the 320 HD patients. In general, there were no observed significant differences between patients' symptoms among studied hospitals at $\mathrm{P}<0.05$. The results showed that the most common basic symptom among the HD patients was hypertension, which was recorded in $77 \%$ of the patients (245 \pm 1.95$)$. Similarly, a previous study conducted by Chavers and colleagues in the USA showed hypertension in more than $79 \%$ of the studied HD patients [16].

The second most common symptom in the patients was diabetes, which was present in $39 \%$ of the patients $(125 \pm 2.6)$, which, importantly, can be probably due to a loss of glucose in the dialysate [17]. However, the observed diabetes incidence in the present study was less than the percentage recorded in a previous study which showed that $50.5 \%$ HD patients had diabetes [10].

Other symptoms included abdominal pain, which was recorded in 33\% (105 \pm 3$)$ of the HD patients. Clinically, the administration of several drugs was related to abdominal pain in HD patients [18].

In addition, $13 \%$ of HD patients $(43 \pm 1.6)$ showed diarrhea symptoms and, therefore, they could also have an increased risk of antibiotics associated with diarrhea [19]. Total bleeding events in HD patients in our sampling centers were only $4 \%(12 \pm 1)$. Bleeding was also less than that reported by Galbusera el al. study [20]. 
Also, the results showed that the incidence of nausea and vomiting during hemodialysis were $21 \%$ (67 \pm 2.8$)$ and $24 \%$ (76 \pm 2.8$)$, respectively. Vomiting percentage is very high when compared to a study conducted by Asgari and colleagues [21] in Tehran, which showed that percentages of patients with nausea and vomiting during hemodialysis were $28.3 \%$ and $11.7 \%$, respectively.

Finally, the results showed that $7 \%$ of HD patients suffered from rash $(23 \pm 1.6)$, which is probably due to the presence of wastes in the bloodstream that the dialyzer membranes could not remove from the blood [22].

Table 2-General patients' symptoms and their comparison among the hospitals studies

\begin{tabular}{|c|c|c|c|}
\hline Symptoms & $\begin{array}{c}\text { Number } \pm \text { SD of } \\
\text { patients }\end{array}$ & $\begin{array}{c}\text { Percentage of } \\
\text { patients }\end{array}$ & $\begin{array}{c}\text { Significant } \\
\text { difference at } \mathbf{0 . 0 5}\end{array}$ \\
\hline Hypertension & $245 \pm 1.95$ & $77 \%$ & $(\mathrm{NS})$ \\
\hline Abdominal pain & $105 \pm 2.98$ & $33 \%$ & $(\mathrm{NS})$ \\
\hline Diabetes & $125 \pm 2.6$ & $39 \%$ & $(\mathrm{NS})$ \\
\hline Diarrhea & $43 \pm 1.6$ & $13 \%$ & $(\mathrm{NS})$ \\
\hline Bleeding & $12 \pm 1$ & $4 \%$ & $(\mathrm{NS})$ \\
\hline Nausea & $67 \pm 2.8$ & $21 \%$ & $(\mathrm{NS})$ \\
\hline Vomiting & $76 \pm 2.8$ & $24 \%$ & $(\mathrm{NS})$ \\
\hline Rash & $23 \pm 1.6$ & $7 \%$ & (NS) \\
\hline
\end{tabular}

NS: Non-Significant.

\section{C - Reactive Protein (CRP)}

The results of CRP concentration in hemodialysis patients are show in Table- 3 . The number of patients who had a CRP concentration below a detection level of $\leq 6 \mathrm{mg} / \mathrm{l}$ was $59 \pm 7.07$ (33\%) male and $49 \pm 7.07(34.5 \%)$ female patients. The maximum positive concentration of CRP ( $\geq 48 \mathrm{mg} / \mathrm{l})$ was $74 \pm 8.5(41.5 \%)$ in male and $62 \pm 8.5(43.6 \%)$ in female patients. Statistical analysis showed no significant differences between male and female groups.

The advantages of CRP test are the lower cost and availability, particularly in developing countries [23]. Serum CRP concentration does not change with the changes in kidney function, but in the early stage of kidney disease, serum CRP may be associated with serum albumin levels that are affected by the inflammatory response [24].

\section{Erythrocyte Sedimentation Rate (ESR)}

The results of ESR concentration in hemodialysis patients are shown in Table-3. The ESR value for the investigated HD males was found to be $91 \%(71 \pm 37)$ and this value was slightly higher than that in females which was $85 \%(65 \pm 34)$. Statistical analysis showed no significant difference between male and female groups, and there was no significant difference between ESR and CRP at $\mathrm{P}<0.05$. In addition, a strongly positive correlation coefficient (0.99) was found between ESR and CRP.

There are very few reports in the medical literature on the usual range and clinical importance of ESR measurement in the HD patients. This is probably because the sedimentation of red cells is greatly influenced as a result of changes in plasma volume caused by the dialysis machines [25]. However, the elevated value of ESR in hemodialysis blood was $87.7 \%$ while Alsomaili et.al recorded $79.5 \%$ on patients with chronic kidney disease [26]. 
Table 3-Inflammation markers (CRP and ESR) for hemodialysis patients and their comparison according to gender

\begin{tabular}{|c|c|c|c|}
\hline $\begin{array}{c}\mathrm{C}-\text { Reactive protein } \\
\mathbf{m g} / \mathbf{l}\end{array}$ & $\begin{array}{c}\text { Value for Males } \\
\text { Number } \pm \text { SD }(\%)\end{array}$ & $\begin{array}{l}\text { Value for Females } \\
\text { Number } \pm \text { SD }(\%)\end{array}$ & $\begin{array}{c}\text { Significant } \\
\text { difference at } 0.05\end{array}$ \\
\hline$<6$ negative & $59 \pm 7.07(33.1 \%)$ & $49 \pm 7.07(34.5 \%)$ & \\
\hline$\geq 6$ positive & $13 \pm 4.24(7.3 \%)$ & $7 \pm 4.24(4.9 \%)$ & \\
\hline$\geq 12$ positive & $15 \pm 5.56(8.4 \%)$ & $7 \pm 5.65(5.9 \%)$ & $(\mathrm{NS})$ \\
\hline$\geq 24$ positive & $17 \pm 0(9.5 \%)$ & $17 \pm 0(11.9 \%)$ & \\
\hline$\geq 48$ positive & $74 \pm 8.5(41.5 \%)$ & $62 \pm 8.5(43.6 \%)$ & \\
\hline $\begin{array}{c}\text { Normal valueESR } \\
\mathrm{mm} / \mathrm{hr}\end{array}$ & $\begin{array}{l}\text { Value for Males } \\
(0-22) \mathrm{mm} / \mathrm{hr}\end{array}$ & $\begin{array}{l}\text { Value for Females } \\
(0-29) \mathrm{mm} / \mathrm{hr}\end{array}$ & $\begin{array}{c}\text { Significant } \\
\text { difference at } 0.05\end{array}$ \\
\hline Mean \pm SD & $71 \pm 37$ & $65 \pm 34$ & \\
\hline Number (negative \%) & $16(8.9 \%)$ & $22(15.5 \%)$ & (NS) \\
\hline Number (positive \%) & $162(91 \%)$ & $120(84.5 \%)$ & \\
\hline \multicolumn{3}{|c|}{ Coefficient correlation between CRP and ESR } & $\begin{array}{c}\text { Significant } \\
\text { difference at } 0.05\end{array}$ \\
\hline \multicolumn{3}{|c|}{0.99} & (NS) \\
\hline
\end{tabular}

NS: Non-Significant; SD: Standard Deviation.

Frequency and Duration Time of Dialysis Sessions

In the present study, the mean duration of hemodialysis in patients on hemodialysis was calculated to be 17.25 months (Table- 4). In Baghdad Educational Center, the majority of the HD patients (94\%) usually take only two sessions per a week for 3 hours. Similar trend was found in Al-Imamain AlJwadian center, where $60 \%$ of the patients take two sessions per a week. In Al-Kindi center, almost half the patients (49\%) take 3 sessions per week, while Al-Yarmouk Center serves $70 \%$ of the patients with 3 sessions per week for 2-3 hours per session.

Thus, the problem with increasing dialysis session time and/or frequency is generally not possible to be solved in the current situation due to the limited number of machines and dialysis centers needed to treat the increasing number of patients [8]. Also, dialysis scheduling is a procedure that some hospitals use to reduce the session's period due to lack of resources.

Table 4-Comparison of both frequency and duration time of dialysis sessions among studied hospitals

\begin{tabular}{|c|c|c|c|c|}
\hline Dialysis & Al-Kindi & $\begin{array}{c}\text { Sig. diff. } \\
\text { at 0.05 }\end{array}$ & $\begin{array}{c}\text { Baghdad } \\
\text { Educational }\end{array}$ & $\begin{array}{c}\text { Sig. diff. } \\
\text { at 0.05 }\end{array}$ \\
\hline $\begin{array}{c}\text { Onset of dialysis in months - } \\
\text { median (range) }\end{array}$ & $12(1-48)$ & (NS) & $5(1-48)$ & (NS) \\
\hline $\begin{array}{c}\text { One times of dialysis sessions in } \\
\text { week }\end{array}$ & $3 \%$ & \multirow{2}{*}{ (NS) } & $94 \%$ & (NS) \\
\hline $\begin{array}{c}\text { Two times of dialysis sessions in } \\
\text { week }\end{array}$ & $48 \%$ & $3 \%$ & \\
\hline $\begin{array}{c}\text { Three times of dialysis sessions in } \\
\text { week }\end{array}$ & $49 \%$ & & $3 \%$ \\
\hline
\end{tabular}




\begin{tabular}{|c|c|c|c|c|}
\hline $\begin{array}{c}\text { Length of dialysis sessions in } \\
\text { hours }\end{array}$ & $3(3)$ & $*$ & $3(3-3.30)$ & $*$ \\
\hline Dialysis & $\begin{array}{l}\text { Al-Imamain Al- } \\
\text { Jwadian }\end{array}$ & $\begin{array}{l}\text { Sig. diff. } \\
\text { at } 0.05\end{array}$ & Al-Yarmouk & $\begin{array}{l}\text { Sig. diff. } \\
\text { at } 0.05\end{array}$ \\
\hline $\begin{array}{l}\text { Onset of dialysis in months median } \\
\text { (range) }\end{array}$ & $\begin{array}{c}19 \\
(1-120)\end{array}$ & $*$ & $\begin{array}{c}33 \\
(1-132)\end{array}$ & (NS) \\
\hline $\begin{array}{l}\text { One times of dialysis sessions in } \\
\text { week }\end{array}$ & $0 \%$ & & $14 \%$ & \\
\hline $\begin{array}{c}\text { Two times of dialysis sessions in } \\
\text { week }\end{array}$ & $60 \%$ & $*$ & $16 \%$ & (NS) \\
\hline $\begin{array}{c}\text { Three times of dialysis sessions in } \\
\text { week }\end{array}$ & $40 \%$ & & $70 \%$ & \\
\hline $\begin{array}{c}\text { Length of dialysis sessions in } \\
\text { hours }\end{array}$ & $3(3-3.30)$ & $*$ & $3(2-3)$ & (NS) \\
\hline
\end{tabular}

* $(\mathrm{P}<0.05)$, NS: Non-Significant.

\section{Conclusions}

It is concluded that the levels of the inflammation markers (CRP and ESR) in the HD patients of dialysis units in Baghdad hospitals are high. The present data showed that the inflammation markers can be used as bioindicators in these pientes.

\section{Acknowledgments:}

The authors would like to thank the staffs of dialysis centers and patients for their kind support to provide the necessary information and appreciate the local ethics committee of the Ministry of Health and Environment, Baghdad, Iraq for approving this study. This study did not receive external funding sources. No potential conflict of interest relevant to this research was reported.

\section{References}

1. Saeed, H.S. and Sinjari, H.Y. 2018. Assessment of hemodialysis efficacy in patients with endstage renal failure in the Erbil hemodialysis center. Medical Journal of Babylon, 15(4): 276-280.

2. Neuen, B. L., Chadban, S. J., Demaio, A. R., Johnson, D W. and Perkovic, V. 2017. Chronic kidney disease and the global NCDs agenda. BMJ Globel Health. 2(2): 2e000380.

3. Di Iorio, B., Di Micco, L., Bruzzese, D., Nardone, L., Russo, L., Formisano, P., D’Esposito, V. and Russo, D. 2017. Ultrapure dialysis water obtained with additional ultrafilter may reduce inflammation in patients on hemodialysis. Journal of Nephrology, 30(6): 795-801.

4. Tentori, F., Zhang, J., Li, Y., Karaboyas, A., Kerr, P., Saran, R., Bommer, J., Port, F., Akiba, T., Pisoni, R. and Robinson, B. 2012. Longer dialysis session length is associated with better intermediate outcomes and survival among patients on in-center three times per week hemodialysis: results from the dialysis outcomes and practice patterns study (DOPPS). Nephrology Dialysis Transplantation, 27(11): 4180-4188.

5. Tamura, M.K., Tam, K., Vittinghoff, E., Raj, D., Sozio, S.M., Rosas, S.E., Makos, G., Lora, C., He, J., Go, A.S. and Hsu, C.Y. 2017. Inflammatory markers and risk for cognitive decline in chronic kidney disease: the CRIC study. Kidney International Reports, 2(2): 192-200.

6. Lavin-Gomez, B.A., Palomar-Fontanet, R., Gago-Fraile, M., Quintanar-Lartundo, J.A., GomezPalomo, E., González-Lamuño, D., García-Unzueta, M.T., Arias-Rodríguez, M.A. and GómezGerique, J.A. 2011. Inflammation markers, chronic kidney disease, and renal replacement therapy. In Advances in peritoneal dialysis. Conference on Peritoneal Dialysis. 27: 33-37.

7. Muslimovic, A., Rasic, S., Tulumovic, D., Hasanspahic, S. and Rebic, D. 2015. Inflammatory markers and procoagulants in chronic renal disease stages 1-4. Medical Archives, 69(5): 307-310.

8. Ali, A., Majeed, YY., Al-Lami FH. and Baldawi K. 2018. Haemodialysis services in Iraq in 2012: situation analysis, epidemiology and infrastructure. Iraqi New Medical Journal, 4(8): 91-99.

9. Al-Naseri, S.K., Mahdi, Z.M. and Hashim, M.F. 2013. Quality of water in hemodialysis centers in B aghdad, I raq. Hemodialysis International, 17(4): 517-522. 
10. Khattak, M., Sandhu, G.S., Desilva, R. and Goldfarb-Rumyantzev, A.S. 2012. Association of education level with dialysis outcome. Hemodialysis International, 16(1): 82-88.

11. Quinn, G.P. and Keough, M.J. 2002. Experimental design and data analysis for biologists. Cambridge University Press.1-539.

12. Malliara, M. 2007. The management of hypertension in hemodialysis and CAPD patients. Hippokratia, 11(4): 171-174.

13. Capizzi, I., Teta, L., Vigotti, F.N., Tognarelli, G., Consiglio, V., Scognamiglio, S. and Piccoli, G.B. 2017. Weight loss in advanced chronic kidney disease: should we consider individualised, qualitative, ad libitum diets? A narrative review and case study. Nutrients, 9(10): 1109-1117.

14. Schneditz, D. 2001. Temperature and thermal balance in hemodialysis. In Seminars in Dialysis, 14(5): 357-364). New York, US: Blackwell Science Inc.

15. Liebman, S.E., Lamontagne, S.P., Huang, L.S., Messing, S. and Bushinsky, D.A. 2011. Smoking in dialysis patients: a systematic review and meta-analysis of mortality and cardiovascular morbidity. American Journal of Kidney Diseases, 58(2): 257-265.

16. Chavers, B.M., Solid, C.A., Daniels, F.X., Chen, S.C., Collins, A.J., Frankenfield, D.L. and Herzog, C.A. 2009. Hypertension in pediatric long-term hemodialysis patients in the United States. Clinical Journal of the American Society of Nephrology, 4(8): 1363-1369.

17. Burmeister, J.E., Miltersteiner, D.R., Burmeister, B.O. and Campos, J.F. 2015. Risk of hypoglycemia during hemodialysis in diabetic patients is related to lower pre-dialysis glycemia. Archives of Endocrinology and Metabolism, 59(2): 137-140.

18. Qian, Y., Chen, X.N., Shi, H., Xie, J.Y. and Chen, N. 2015. Refractory abdominal pain in a hemodialysis patient. Nephrology and Dialysis, 5(2): 145-151.

19. Higashihara, T., Okada, A., Kishida, Y., Maruno, S., Matsumura, M., Tamura, K. and Takano, H. 2018. Atypical cause of intractable diarrhea in a hemodialysis patient, masked by Clostridium difficile-associated diarrhea and ischemic colitis: a case report. Nephrology, 19(1): 303-311.

20. Galbusera, M., Remuzzi, G. and Boccardo, P. 2009. Treatment of bleeding in dialysis patients.In Seminars in Dialysis, 22(3): 279-286.

21. Asgari, M.R., Asghari, F., Ghods, A.A., Ghorbani, R., Motlagh, N.H. and Rahaei, F. 2017. Incidence and severity of nausea and vomiting in a group of maintenance hemodialysis patients. Journal of Renal Injury Prevention, 6(1): 49-55.

22. Meyrier, A., Shiell, K. A., and Andrews, P. A. 2011. A painful skin rash in a patient with Stage V chronic kidney disease. Nephrology Dialysis Transplantation Pluss, 4(3): 201-204.

23. Helal, I., Zerelli, L., Krid, M., ElYounsi, F., Maiz, H.B., Zouari, B., Adelmoula, J. and Kheder, A.2012. Comparison of c-reactive protein and high-sensitivity c-reactive protein levels in patients on hemodialysis. Saudi Journal of Kidney Diseases and Transplantation, 23(3): 477-483.

24. Heidari, B. 2013. C-reactive protein and other markers of inflammation in hemodialysis patients. Caspian Journal of Internal Medicine, 4(1): 611-616.

25. Etim, E.A. 2018. Effect of maintenance hemodialysis on red cell indices and erythrocyte sedimentation rate in northeast Nigeria. Journal of Hematology, 3(1): 17-22.

26. Alsomaili, M.I., Yousuf, M., Hejaili, F., Almotairi, W. and Al-Sayyari, A.A.2015. Erythrocyte sedimentation rate in stable patients on chronic hemodiaysis. Saudi Journal of Kidney Diseases and Transplantation, 26(6): 1149-1153. 